\title{
Childhood overgrowth in patients with common NF1 microdeletions
}

\author{
Miriam Spiegel $^{1}$, Konrad Oexle ${ }^{2,3}$, Denise Horn ${ }^{1}$, Elke Windt ${ }^{3}$, Annegret Buske ${ }^{4}$, Beate \\ Albrecht $^{5}$, Eva-Christina Prott ${ }^{5}$, Eva Seemanová ${ }^{6}$, Joerg Seidel $^{7}$, Thorsten Rosenbaum ${ }^{8}$, \\ Dieter Jenne ${ }^{9}$, Hildegard Kehrer-Sawatzki ${ }^{10}$ and Sigrid Tinschert*,1,2
}

${ }^{1}$ Institut für Medizinische Genetik, Charité, Humboldt-Universität, Berlin, Germany; ${ }^{2}$ Institut für Klinische Genetik, Medizinische Fakultät Carl Gustav Carus, TU Dresden, Germany; ${ }^{3}$ Otto-Heubner-Centrum für Kinder- und Jugendmedizin, Charité, Humboldt-Universität, Berlin, Germany; ${ }^{4}$ Praxis für Medizinische Genetik, Medizinisches Zentrum Lichtenberg, Berlin, Germany; ${ }^{5}$ Institut für Humangenetik, Universitätsklinikum Essen, Germany; ${ }^{6}$ Department of Clinical Genetics, Charles University Hospital Prague-Motol, Czech Republic; ${ }^{7}$ Klinik für Kinder- und Jugendmedizin Gera, Lehrkrankenhaus der Friedrich-Schiller-Universität Jena, Germany; ${ }^{8}$ Klinik für Allgemeine Pädiatrie, Universitätsklinikum Düsseldorf, Germany; ${ }^{9}$ Abteilung Neuroimmunologie, Max-Planck-Institut für Neurobiologie, Planegg Martinsried, Germany; ${ }^{10}$ Abteilung Humangenetik, Universität Ulm, Germany

While growth retardation and short stature are well-known features of patients with classical neurofibromatosis type 1 (NF1), we found advanced height growth and accelerated carpal bone age in patients with an NF1 microdeletion. Our analysis is based on growth data of 21 patients with common 1.4/1.2 Mb microdeletions, including three patients with a Weaver-like appearance. Overgrowth was most evident in preschool children (2-6 years, $n=10, P=0.02$ ). We conclude that childhood overgrowth is part of the phenotypic spectrum in patients with the common 1.4/1.2 Mb NF1 microdeletions and assume that the chromosomal region comprised by the microdeletions contains a gene whose haploinsufficiency causes overgrowth.

European Journal of Human Genetics (2005) 13, 883-888. doi:10.1038/sj.ejhg.5201419

Published online 27 April 2005

Keywords: NF1 microdeletions; overgrowth; Weaver syndrome

\section{Introduction}

Growth alterations in neurofibromatosis 1 (NF1) have first been described in the early 1950s. ${ }^{1}$ Today, short stature and macrocephaly are well-recognized traits of this disorder. ${ }^{2-9}$ Another form of growth anomaly associated with NF1 was reported by van Asperen et al, who observed the combination of NF1 with overgrowth and features resembling Weaver syndrome in a mother and her son. They attributed this unusual phenotype to a large NF1 microdeletion in

*Correspondence: Dr S Tinschert, Institut für Klinische Genetik, Medizinische Fakultät Carl Gustav Carus, Fetscherstr. 74, 01307 Dresden, Germany. Tel: + 49351458 4278; Fax: + 49351458 4316; E-mail: sigrid.tinschert@mailbox.tu-dresden.de

Received 14 September 2004; revised 10 February 2005; accepted 3 March 2005 17q11.2. ${ }^{10}$ Weaver syndrome, first reported in 1974 , is characterized by overgrowth in childhood (both height and occipitofrontal head circumference (OFC) above the 97th centile), markedly advanced carpal bone age, developmental delay, and distinctive facial appearance. ${ }^{11}$ The genetic basis of this mostly sporadic syndrome has not been completely elucidated. Although Douglas et al (2003) and Rio et al (2003) found NSD1 mutations in a group of patients with a diagnosis of Weaver syndrome, NSD1 mutations could not be detected in other Weaver syndrome patients. ${ }^{12-14}$

In approximately $5 \%$ of all cases, NF1 is caused by microdeletions in 17q11.2. ${ }^{15-17}$ The most common deletion (type I) encompasses $1.4 \mathrm{Mb}$ and comprises 14 genes. The less frequent type II deletion spans $1.2 \mathrm{Mb}$ and 
contains only 13 of these genes. ${ }^{18,19}$ The breakpoints of type I deletions are localized within the NF1 low-copy repeats (LCRs), those of type II deletions are within the JJAZ1 gene and its pseudogene, suggesting that both deletions result from unequal homologous recombination. ${ }^{19-21}$ Patients with NF1 microdeletions present with a recognizable phenotype: (i) early and severe manifestation of NF1 signs, that is, development of neurofibroma and increased risk of malignancy, (ii) coarse facial appearance with prominent nose and large ears, and (iii) mild to moderate mental retardation.

Although a large number of reports dealing with NF1 microdeletions have been published since the first report by Kayes et $a^{22}$ in 1992, little is known about growth profiles in such patients. Here, we report the growth data of 21 patients with the common $1.4 / 1.2 \mathrm{Mb} N F 1$ microdeletions. In contrast to classical NF1, overgrowth - particularly during childhood - is a frequent finding in these patients. Weaver-like features in three of them confirm a case report by van Asperen et $a l^{10}$ (see above) and indicate that Weaver-like appearance belongs to the phenotypic spectrum associated with the common NF1 microdeletions.

\section{Patients and methods}

Clinical data were taken into account up to the date of submission of the present paper. Values of height and OFC were available for 21 patients with the common $1.4 / 1.2 \mathrm{Mb}$ NF1 microdeletions (16 children and five adults, including three parent-child pairs, LIY-LIR, WEM-WER, KAA-KAE). The age of the 13 male patients ranged from 0 (birth) to 31 years, the age of the eight females from 2 to 45 years.

The presence and extension of the NF1 microdeletions were determined as described by Tinschert et al. ${ }^{23}$ In all, 19 patients had a type I deletion, as indicated by the lack of BAC 307A16 hybridization. In two patients (the parentchild pair LIY-LIR), this BAC clone produced a reduced signal intensity suggestive of a type II deletion. ${ }^{19}$ Patients with unusual deletions (ie, smaller or larger than the 1.4/ 1.2 $\mathrm{Mb}$ common deletions) were not included in the study.

In three patients (COS, ERS, PFA), the facial aspect reminded of Weaver syndrome (Figure 2). In two of them (COS and PFA), the deletion breakpoints were determined by deletion junction-specific PCRs and found to be located in the $4 \mathrm{~kb}$ hotspot interval of the type I deletion. ${ }^{24,25}$

Four patients with optic pathway glioma were not included in the present study since optic glioma is a rare cause of overgrowth and precocious puberty. ${ }^{26-30}$ Precocious puberty was noticed in patient COS. However, it occurred at a borderline age of 7.8 years. Therefore, his early growth data (until the age of 6 years) and bone age data (determined at an age of 1.5 years) were taken into account. Other anatomical abnormalities reported to occur in NF1 microdeletion patients such as callosal dysgenesis
(GUN) or agenesis (WEH), septum pellucidum cyst (SCH), moderate dilation of lateral ventricles (KRE, WEH), and non-occlusive aqueductal stenosis (WER) did not lead to exclusion. ${ }^{31}$ Brain MRIs were available for the majority of patients in this study (BAH, BUC, COS, HIN, KRE, LIR, MUE, PFA, SCH, WEH, WEM, WER, and WOL).

Height and OFC data of the patients were compared to general population and NF1 standard growth charts (http://www.medgen.ubc.ca/friedmanlab/growthpatterns/ growthpatterns.html). ${ }^{8}$ Carpal and phalangeal bone age was assessed according to the standard method of Greulich and Pyle using X-ray images of the left hand.

\section{Statistical analysis}

The length data of male and female probands were compared to the respective distributions of both the general population and the NF1 population. Statistical analysis was performed in the age group of preschool children between 2 and 6 years. The mean $\mu(t)$ and standard deviation $\sigma(t)$ of every age $t$ in this group were calculated from the $P_{50}(t)$ and $P_{95}(t)$ centiles of the reference populations (see Figure 1 ) by assuming normal distributions, that is, $\mu(t)=P_{50}(t) \quad$ and $1.65 \sigma(t)=P_{95}(t)-P_{50}(t) .^{8,32}$ Then, in order to overcome the age dependency of the data, the deviation of each proband's length $L_{i}(t)$ from the age-dependent mean $\mu(t)$ was divided by the age-dependent standard deviation $\sigma(t)$. Thus, an age-independent standard deviation score $Z_{i}=\left(L_{i}(t)-\mu(t)\right) / \sigma(t)$ was produced for each proband's length. If the length data of a proband were available from different ages, the average of the proband's $z$-scores was used in the statistical analysis. For calculation of the significance level $P, \bar{Z}$ was divided by its estimated standard deviation and compared to a Student's distribution with $(n-1)$ degrees of freedom (ie, one-sample $t$-test). ${ }^{32}$ Statistical analyses of head size (OFC) and of predicted adult height (ie, average of the parents' heights plus $6.5 \mathrm{~cm}$ in boys and minus $6.5 \mathrm{~cm}$ in girls, respectively ${ }^{33}$ ) were performed analogously.

\section{Results}

Height growth data are depicted in Figure 1. Overgrowth at preschool age (2-6 years) is evident. Data from this age were available for $n=7$ male patients. With one exception (NOI), all were at or above the 95th centile of classical NF1. Five of them even were at or above the 95th centile of the general population. The average standard deviation score $\bar{Z}$ of male NF1 microdeletion patients in the age group of $2-6$ years was $1.4(P=0.01)$ compared to the general population and $1.8(P=0.005)$ compared to the classical NF1 population. The average predicted adult height of these patients as derived from the parents' heights did not differ significantly from male adult height in the general population $($ mean $\pm \mathrm{SD}=179.7 \pm 5.5 \mathrm{~cm}, \bar{Z}=0.40, P=0.24)$. 
a

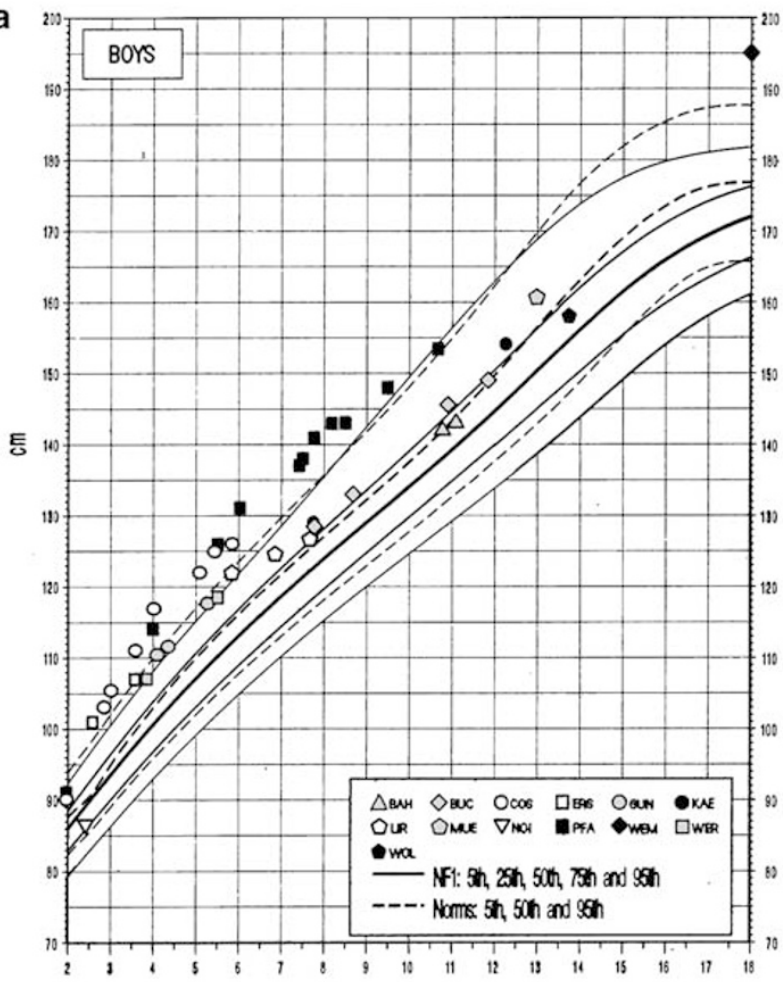

C

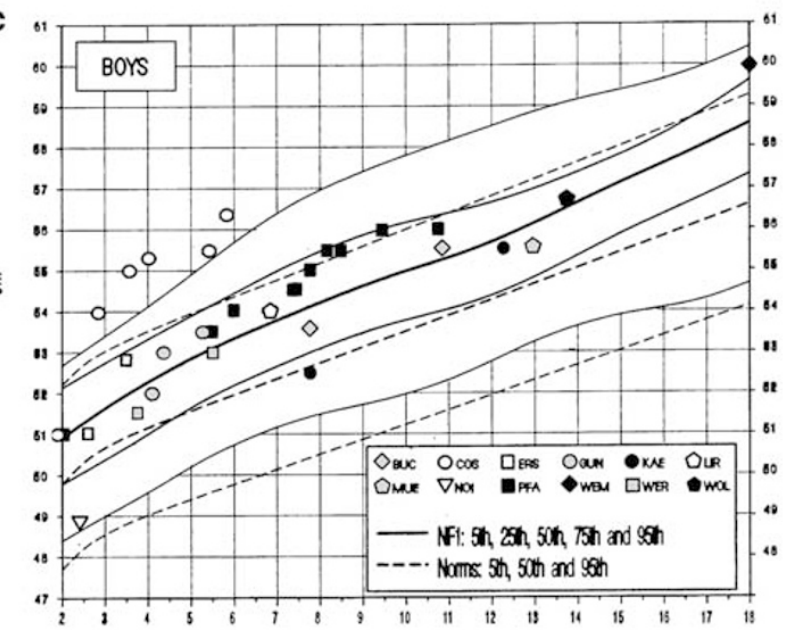

b
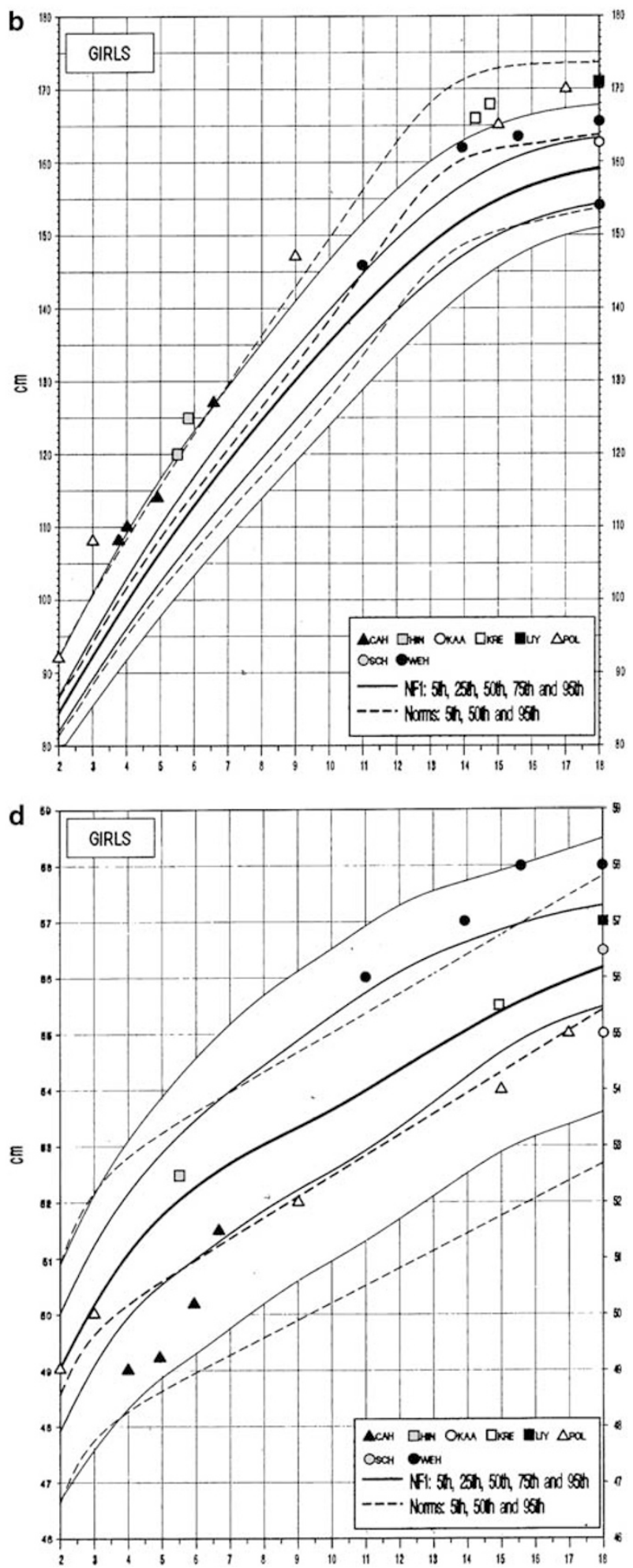

Figure 1 Growth of height and OFC in patients with common NF1 microdeletions. Height, males (a) and females (b). OFC, males (c) and females (d). Growth charts are available at http://www.medgen.ubc.ca/friedmanlab/growthpatterns/growthpatterns.html. 
Data were less abundant in older patients. However, during the second decade all patients were above the 50th, most of them at or above the 75th centile of classical NF1 and, with one exception (WOL), at or above the 50th centile of the general population. For adult male patients data were sparse.

Similar to the male patients, preschool height measures of female patients with common NF1 microdeletions (available for $n=3$ patients) were at or above the 95th centiles $(\bar{Z}=2.2, P=0.01$, if compared to the general population; and $\bar{Z}=2.0, P=0.01$, if compared to the classical NF1 population). As in the male group, the average predicted adult height of preschool girls did not differ significantly from female adult height in the general population (mean $\pm \mathrm{SD}=167.5 \pm 3.6 \mathrm{~cm}, \bar{Z}=0.66, P=0.09$ ). The height of five adolescent and adult females was above the 75th centile of classical NF1 and above the 50th centile of the general population. The short stature of patient $\mathrm{SCH}$ was at least in part due to her scoliosis.

A combination of male and female probands' height data at age $2-6$ years $(n=10)$ resulted in $\bar{Z}=1.7, P<0.001$, compared to the general population; and $\bar{Z}=1.8, P<0.001$, compared to the classical NF1 population, whereas the average predicted adult height based on parent's heights was not significantly increased $(\bar{z}=0.48, P=0.11)$. If (in order to exclude an influence of familial growth patterns definitively) for each proband the predicted height score (based on parent's heights) was subtracted from the presented height score (based on individual lengths data), childhood overgrowth was also significant $(\bar{z}=1.2$, $P=0.02$, compared to the general population; and $\bar{Z}=1.3$, $P=0.01$, compared to the classical NF1 population).

Head sizes (OFC) of NF1 microdeletion patients were similar to patients with intragenic mutations and, as expected, larger than those of the general population. In boys, the difference from the general population was significant $(P=0.03)$ already at the age of $2-6$ years and became obvious in both genders when older probands were included in the analysis (males, $P=0.002$; females, $P=0.05$; data not shown).

Table 1 Carpal and phalangeal bone age acceleration

\begin{tabular}{lccc}
\hline Patient & $\begin{array}{c}\text { Chronological } \\
\text { age (years) }\end{array}$ & $\begin{array}{c}\text { Carpal bone age } \\
\text { acceleration } \\
\text { (years) }\end{array}$ & $\begin{array}{c}\text { Phalangeal bone } \\
\text { age acceleration } \\
\text { (years) }\end{array}$ \\
\hline COS & 1.42 & +1.58 & +1.08 \\
PFA & 1.58 & +0.42 & -0.08 \\
& 6.25 & +2.75 & -0.25 \\
ERS & 2.66 & +0.84 & +0.16 \\
& 3.50 & +1.00 & +1.00 \\
WER & 4.25 & +1.25 & +0.75 \\
GUN & 4.50 & +2.00 & +2.00 \\
LIR & 6.83 & +0.77 & +1.17 \\
KAE & 12.25 & +1.75 & +1.75 \\
MUE & 13.00 & +0.50 & +0.50
\end{tabular}

Bone age data were available from eight patients (Table 1). In six patients (COS, ERS, GUN, KAE, PFA, WER), carpal bone age was advanced by more than one year, four of them (COS, GUN, LIR, KAE) also showed advanced phalangeal age.

\section{Discussion}

Macrocephaly and short stature are regarded as distinctive traits of NF1 and result from NF1 haploinsufficiency. Several groups published anthropometric measurements and growth charts for NF1 patients. ${ }^{6-9,34}$ It was shown that height growth was nearly normal during childhood but decreased with increasing age.6,7,9 Patients with the common NF1 microdeletions, however, display distinct growth anomalies. In contrast to classical NF1 patients, childhood overgrowth occurs in these patients. Previously published data on individual patients with NF1 microdeletions are sparse and an age dependency of their growth patterns has not been reported. Fragmentary information on 43 patients can be found in the literature. In support of our results, 12 of those were also reported with overgrowth or advanced growth (above the 90th centile of the general population). ${ }^{10,16,35-40}$

In addition to childhood overgrowth, we found evidence of bone age acceleration in NF1 microdeletion patients. This also contrasted with findings in classical NF1 patients whose prepubertal bone age is delayed by $1-2$ years. ${ }^{6}$

The cause of childhood overgrowth in patients with NF1 microdeletions remains to be elucidated. Precocious puberty is a possible explanation. However, precocious puberty occurred only in one of our patients (COS) and not before he was 7.8 years old. Optic glioma, a rare cause of overgrowth in some patients with classical NF1, cannot serve as a general explanation of the observed overgrowth in NF1 microdeletion patients; furthermore, optic glioma led to exclusion from the present study. ${ }^{26-30}$ Incidentally, however, the boy reported by van Asperen et $a l^{10}$ had an optic glioma. ${ }^{16}$

We suggest that haploinsufficiency of a gene located within the common NF1 microdeletions - but different from the NF1 gene itself - may cause increased growth during childhood, possibly by influencing skeletal maturation. On the basis of our data, it is not yet possible to make a definitive statement concerning adolescent height growth of patients with common NF1 microdeletions.

Simultaneous occurrence of NF1 and overgrowth reminiscent of Weaver syndrome was reported before in a mother and her son who had a large microdeletion in 17q11.2. ${ }^{10,16}$ Weaver syndrome was suspected because in addition to overgrowth there was advanced skeletal maturation, craniofacial dysmorphism, developmental delay, prominent fingerpads, and umbilical hernia. ${ }^{11,41}$ In 

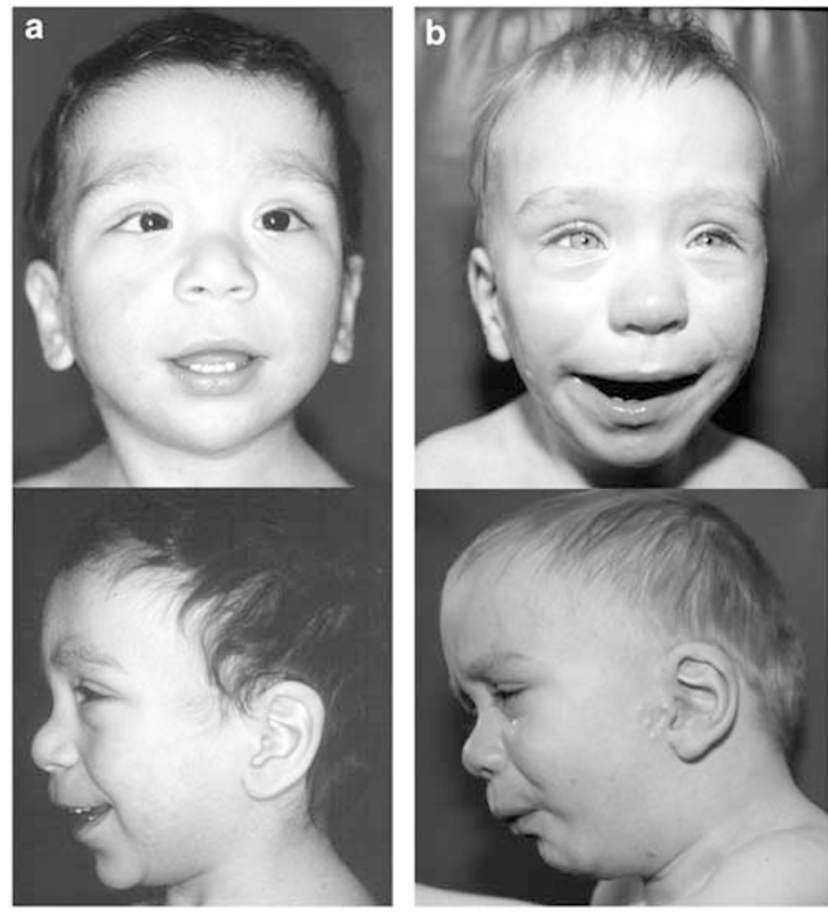

Figure 2 Facial appearance of patients $\operatorname{COS}(\mathbf{a})$ and PFA (b) with features resembling Weaver syndrome, that is, coarse face, broad forehead, broad nasal bridge, epicanthus, long and prominent philtrum, retrognathia, large ears, and short neck. Other features typical of Weaver syndrome but not present in other NF1 microdeletion patients were not observed.

their facial appearance, the patients COS, PFA (Figure 2), and ERS closely resemble this overlapping NF1-Weaver-like phenotype. As determined by FISH analysis, all three patients have the common $1.4 \mathrm{Mb}$ spanning deletion type I. For patients COS and PFA, it was possible to assign the breakpoints within the NF1 LCRs to a $4 \mathrm{~kb}$ hotspot interval of deletion breakpoints. ${ }^{25}$

Patients with NF1 microdeletions usually present with learning disability or mental retardation, coarse face with broad nasal bridge, down-slanting palpebral fissures, large nose, small/pointed chin, large ears with thick helices, and macrocephaly. ${ }^{16,22,35,37-39,42-48}$ Our data indicate that childhood overgrowth and, in some cases, Weaver-like facial appearance belong to the phenotypic spectrum associated with the common NF1 microdeletions. If occurring in patients with NF1, these signs should prompt the appropriate molecular cytogenetic evaluation.

At present, most of the genes from the deleted interval are completely uncharacterized and information on their expression during bone maturation and growth is not available. Overgrowth and anomalies of bone maturation have been observed in autosomal dominant syndromes such as Sotos syndrome (associated with NSD1 mutations, OMIM \#117550), and Bannayan-Riley-Ruvalcaba syn- drome (PTEN, OMIM \#153480). These syndromes are caused by anomalies in receptor-mediated signalling pathways (PTEN) or transcriptional regulation (NSD1). With these dominantly inherited syndromes in mind, we are being enticed to speculate that one of the partially characterized genes, centaurin alpha-2 (CENT2A), a regulator of phosphoinositide signalling or JJAZ1/SUZ12, a regulator of histone methylation, is modifying the NF1 phenotype due to a partial loss of functional activity. ${ }^{49-52}$ The hemizygous expression of such a gene may also facilitate the growth and progression of neurofibromas after the loss of the second normal NF1 allele. Further evaluation of these genes during bone development and maturation will clarify whether the deletion of one or both of them is a genuine cause of overgrowth including a Weaver-like phenotype and of the accelerated tumor growth in patients with the $17 \mathrm{q} 11.2$ common microdeletions.

\section{Acknowledgements}

We thank Karin Lehmann for excellent technical assistance. We are obliged to unknown reviewers for their helpful comments. This work was supported in part by the Deutsche Krebshilfe (Contact grant number 70-3075-Ti I).

\section{References}

1 Wilkins L: The Diagnosis and Treatment of Endocrine Disorders in Childhood and Adolescence. Springfield, IL: Charles C Thomas, 1950.

2 Carey JC, Laub JM, Hall BD: Penetrance and variability in neurofibromatosis: a genetic study of 60 families. Birth Defects Orig Artic Ser 1979; 15: 271-281.

3 Riccardi VM (ed): Neurofibromatosis: Phenotype, Natural History, and Pathogenesis. Baltimore: Johns Hopkins University Press, 1992.

4 North K: Neurofibromatosis type 1: review of the first 200 patients in an Australian clinic. J Child Neurol 1993; 8: 395-402.

5 Huson SM, Hughes RAC (eds): The Neurofibromatoses - A Pathogenetic and Clinical Overview. London: Chapman \& Hall, 1994.

6 Carmi D, Shohat M, Metzker A, Dickerman Z: Growth, puberty, and endocrine functions in patients with sporadic or familial neurofibromatosis type 1: a longitudinal study. Pediatrics 1999; 103: $1257-1262$.

7 Clementi M, Milani S, Mammi I, Boni S, Monciotti C, Tenconi R: Neurofibromatosis type 1 growth charts. Am J Med Genet 1999; 87: 317-323.

8 Szudek J, Birch P, Friedman JM: Growth in North American white children with neurofibromatosis 1 (NF1). J Med Genet 2000; 37: 933-938.

9 Virdis R, Street ME, Bandello MA et al: Growth and pubertal disorders in neurofibromatosis type 1. J Pediatr Endocrinol Metab 2003; 16 (Suppl 2): 289-292.

10 Van Asperen CJ, Overweg-Plandsoen WC, Cnossen MH, van Tijn DA, Hennekam RC: Familial neurofibromatosis type 1 associated with an overgrowth syndrome resembling Weaver syndrome. J Med Genet 1998; 35: 323-327.

11 Weaver DD, Graham CB, Thomas IT, Smith DW: A new overgrowth syndrome with accelerated skeletal maturation, unusual facies, and camptodactyly. J Pediatr 1974; 84: 547-552. 
12 Douglas J, Hanks S, Temple IK et al: NSD1 mutations are the major cause of Sotos syndrome and occur in some cases of Weaver syndrome but are rare in other overgrowth phenotypes. Am J Hum Genet 2003; 72: 132-143.

13 Rio M, Clech L, Amiel J et al: Spectrum of NSD1 mutations in Sotos and Weaver syndromes. J Med Genet 2003; 40: 436-440.

14 Turkmen S, Gillessen-Kaesbach G, Meinecke P et al: Mutations in NSD1 are responsible for Sotos syndrome, but are not a frequent finding in other overgrowth phenotypes. Eur J Hum Genet 2003; 11: $858-865$.

15 Ainsworth PJ, Chakraborty PK, Weksberg R: Example of somatic mosaicism in a series of de novo neurofibromatosis type 1 cases due to a maternally derived deletion. Hum Mutat 1997; 9: $452-457$.

16 Cnossen $\mathrm{MH}$, van der Est MN, Breuning $\mathrm{MH}$ et al: Deletions spanning the neurofibromatosis type 1 gene: implications for genotype-phenotype correlations in neurofibromatosis type 1 ? Hum Mutat 1997; 9: 458-464.

17 Kluwe L, Siebert R, Gesk S et al: Screening 500 unselected neurofibromatosis 1 patients for deletions of the NF1 gene. Hum Mutat 2004; 23: 111-116.

18 Jenne DE, Tinschert S, Dorschner MO, Hameister H, Stephens K, Kehrer-Sawatzki H: Complete physical map and gene content of the human NF1 tumor suppressor region in human and mouse. Genes Chromosomes Cancer 2003; 37: 111-120.

19 Kehrer-Sawatzki H, Kluwe L, Sandig C et al: High frequency of mosaicism among patients with neurofibromatosis type 1 (NF1) with microdeletions caused by somatic recombination of the JJAZ1 gene. Am J Hum Genet 2004; 75: 410-423.

20 López-Correa C, Brems H, Lazaro C et al: Molecular studies in 20 submicroscopic neurofibromatosis type 1 gene deletions. Hum Mutat 1999; 14: 387-393.

21 Jenne DE, Tinschert S, Stegmann E et al: A common set of at least 11 functional genes is lost in the majority of NF1 patients with gross deletions. Genomics 2000; 66: 93-97.

22 Kayes LM, Riccardi VM, Burke W, Bennett RL, Stephens K: Large de novo DNA deletion in a patient with sporadic neurofibromatosis 1, mental retardation, and dysmorphism. J Med Genet 1992; 29: $686-690$.

23 Tinschert S, Naumann I, Stegmann E et al: Segmental neurofibromatosis is caused by somatic mutation of the neurofibromatosis type 1 (NF1) gene. Eur J Hum Genet 2000; 8: 455-459.

24 Jenne DE, Tinschert S, Stegmann E et al: A common set of at least 11 functional genes is lost in the majority of NF1 patients with gross deletions. Genomics 2000; 66: 93-97.

25 Jenne DE, Tinschert S, Reimann $\mathrm{H}$ et al: Molecular characterization and gene content of breakpoint boundaries in patients with neurofibromatosis type 1 with 17q11.2 microdeletions. Am J Hum Genet 2001; 69: 516-527.

26 Crawford MJ, Buckler JM: Optic gliomata affecting twins with neurofibromatosis. Dev Med Child Neurol 1983; 25: 370-373.

27 Duchowny MS, Katz R, Bejar RL: Hypothalamic mass and gigantism in neurofibromatosis: treatment with bromocriptine. Ann Neurol 1984; 15: 302-304.

28 Manski TJ, Haworth CS, Duval-Arnould BJ, Rushing EJ: Optic pathway glioma infiltrating into somatostatinergic pathways in a young boy with gigantism. Case report. J Neurosurg 1994; 81: 595-600.

29 Fuqua JS, Berkovitz GD: Growth hormone excess in a child with neurofibromatosis type 1 and optic pathway tumor: a patient report. Clin Pediatr (Phila) 1998; 37: 749-752.

30 Drimmie FM, MacLennan AC, Nicoll JA, Simpson E, McNeill E, Donaldson MD: Gigantism due to growth hormone excess in a boy with optic glioma. Clin Endocrinol (Oxf) 2000; 53: $535-538$

31 Korf BR, Schneider G, Poussaint TY: Structural anomalies revealed by neuroimaging studies in the brains of patients with neurofibromatosis type 1 and large deletions. Genet Med 1999; 1: $136-140$
32 Sachs L: Angewandte Statistik. 8th edn. Berlin: Springer, 1997, p 341.

33 Prader A, Budliger $\mathrm{H}$ : Body measurements, growth velocity and bone age of healthy children up to 12 years of age (longitudinal growth study Zurich). Helv Paediatr Acta 1977; 37 (Suppl): 1-44.

34 DiMario Jr FJ, Bowers P, Jagjivan B, Burleson J, Langshur S, Greenstein RM: Analysis of skull anthropometric measurements in patients with neurofibromatosis type-1. Invest Radiol 1993; 28: 116-120.

35 Kaplan P, Rosenblatt B: A distinctive facial appearance in neurofibromatosis von Recklinghausen. Am J Med Genet 1985; 21: $463-470$.

36 Leppig KA, Kaplan P, Viskochil D, Weaver M, Ortenberg J, Stephens K: Familial neurofibromatosis 1 microdeletions: cosegregation with distinct facial phenotype and early onset of cutaneous neurofibromata. Am J Med Genet 1997; 73: 197-204.

37 Valero MC, Pascual-Castroviejo I, Velasco E, Moreno F, Hernandez-Chico C: Identification of de novo deletions at the NF1 gene: no preferential paternal origin and phenotypic analysis of patients. Hum Genet 1997; 99: 720-726.

38 López-Correa C, Brems H, Lazaro C, Marynen P, Legius E: Unequal meiotic crossover: a frequent cause of NF1 microdeletions. Am J Hum Genet 2000; 66: 1969-1974.

39 Dorschner MO, Sybert VP, Weaver M, Pletcher BA, Stephens K: NF1 microdeletion breakpoints are clustered at flanking repetitive sequences. Hum Mol Genet 2000; 9: 35-46.

40 Venturin M, Guarnieri P, Natacci F et al: Mental retardation and cardiovascular malformations in NF1 microdeleted patients point to candidate genes in 17q11.2. J Med Genet 2004; 41: 35-41.

41 Ardinger HH, Hanson JW, Harrod MJ et al: Further delineation of Weaver syndrome. J Pediatr 1986; 108: 228-235.

42 Kayes LM, Burke W, Riccardi VM et al: Deletions spanning the neurofibromatosis 1 gene: identification and phenotype of five patients. Am J Hum Genet 1994; 54: 424-436.

$43 \mathrm{Wu}$ BL, Austin MA, Schneider GH, Boles RG, Korf BR: Deletion of the entire NF1 gene detected by the FISH: four deletion patients associated with severe manifestations. Am J Med Genet 1995; 59: $528-535$.

44 Colley A, Donnai D, Evans DG: Neurofibromatosis/Noonan phenotype: a variable feature of type 1 neurofibromatosis. Clin Genet 1996; 49: 59-64.

45 Leppig KA, Viskochil D, Neil S et al: The detection of contiguous gene deletions at the neurofibromatosis 1 locus with fluorescence in situ hybridization. Cytogenet Cell Genet 1996; 72: 95-98.

46 Upadhyaya $\mathrm{M}$, Roberts $\mathrm{SH}$, Maynard $\mathrm{J}$ et al: A cytogenetic deletion, $\operatorname{del}(17)(\mathrm{q} 11.22 \mathrm{q} 21.1)$, in a patient with sporadic neurofibromatosis type 1 (NF1) associated with dysmorphism and developmental delay. J Med Genet 1996; 33: 148-152.

47 Tonsgard JH, Yelavarthi KK, Cushner S, Short MP, Lindgren V: Do NF1 gene deletions result in a characteristic phenotype? Am J Med Genet 1997; 73: 80-86.

48 Riva P, Corrado L, Natacci F et al: NF1 microdeletion syndrome: refined FISH characterization of sporadic and familial deletions with locus-specific probes. Am J Hum Genet 2000; 66: 100-109.

49 Whitley P, Gibbard AM, Koumanov F et al: Identification of centaurin-alpha2: a phosphatidylinositide-binding protein present in fat, heart and skeletal muscle. Eur J Cell Biol 2002; 81: $222-230$.

50 Hanck T, Stricker R, Sedehizade F, Reiser G: Identification of gene structure and subcellular localization of human centaurin alpha 2 , and p42IP4, a family of two highly homologous, Ins 1,3,4,5P4-/PtdIns 3,4,5-P3-binding, adapter proteins. J Neurochem 2004; 88: $326-336$.

51 Cao R, Zhang Y: SUZ12 is required for both the histone methyltransferase activity and the silencing function of the EED-EZH2 complex. Mol Cell 2004; 15: 57-67.

52 Pasini D, Bracken AP, Jensen MR, Denchi EL, Helin K: Suz12 is essential for mouse development and for EZH2 histone methyltransferaseactivity. EMBO J 2004; 23: 4061-4071. 